\title{
Sciendo
}

ACTA UNIVERSITATIS CIBINIENSIS - TECHNICAL SERIES

Vol. 712019

\section{METHODS OF ACADEMIC EDUCATION IN THE FIELD OCCUPATIONAL SAFETY AND HEALTH - ANALYSIS OF APPLIED SOLUTIONS IN THE OPINION OF STUDENTS, EMPLOYEES AND EMPLOYERS}

\author{
Tomasz Lis \\ Czestochowa University of Technology, Faculty of Management, 42-200 Czestochowa, Poland
}

\begin{abstract}
Methods of education applied at universities have a direct impact on matching of knowledge, skills, but also on the approach to the professional sphere of graduates, in relation to the needs and requirements of employers. It is particularly important in the case of Occupational Safety and Health field of study. Using the available means of technical and informational support of education, one should concentrate on shaping individual thinking. In times of rapid technological development, it is not the duplication that counts, but the creative thinking that must be accompanied by the ability to work in a group. And in this direction, according to the author, academic education should pursue. In the publication, the author analyses the applied methods of education. For this purpose, the results of the study of the participant's observation, direct interviews with employees and employers, as well as the results of a survey conducted among students of the Czestochowa University of Technology, will be used. The analysis will be carried out in terms of the evaluation of applied methods of education - quality, usefulness, adjustment to expectations (students and employers), attractiveness of form and content.
\end{abstract}

\section{Introduction}

The idea of taking up the issues of applied education methods in the field of occupational health and safety, arose during the interviews conducted by the author with: business owners, employees and students. These interviews have pointed the fact that the importance of OSH for the functioning of modern enterprises is perceived and understood. At the same time health and safety issues still appeared to be underestimated. The approach, according to which the management of occupational safety and health is important, and at the same time treated a bit with the "tongue in cheek" gives food for thought. What affects the understanding of the overall importance of health and safety management? What affects the treatment of the issue of actual security without due seriousness? How should the education process in higher education, in the field of health and safety be carried out? What qualities should academic teachers characterize to transfer knowledge effectively? What do students expect when choosing health and safety field of study? These issues are only part of the questions, the author of the publication will try to find answers to.

\section{Health and Safety as a field of study related to management}

Those, who begin their studies at higher education, decide to "thoroughly explore, investigate something (...), to familiarize themselves with something, watching or reading something carefully"[1] . They decide to acquire knowledge on topics consistent with their chosen direction. The goal is individual development, which is to allow the individual to achieve the intended results, which can include: finance, contentment, self-fulfillment.

The article discusses the subject of academic education in the field of health and safety. Human functioning is related to planning, organizing, controlling, supervising activities that are carried out by him or in which he participates directly or indirectly. It is nothing but management[2]. One of the basic needs of man in every aspect of his daily life is safety. It decides mostly about taking or not taking action. It affects the efficiency of functioning. This dependence also applies to business management.

Obtaining knowledge in the field of health and safety meets the issues outlined in the definition of the health and safety management system. According to the definition, this system "is all means, legal, technical and organizational measures that aim at protecting a person in the work process against hazards resulting from the material working environment as well as against occupational diseases and accidents at work"[3]. Currently, more and more often in the literature, attention is paid to the impact of health and safety management on the competitive position of enterprises.[4] 
In connection with the above, the organization and management of the occupational health and safety system is becoming the strategic task in enterprises. It is not only about physical security resulting from prevention and counteracting the possibilities of situations that pose a threat to human health and life. It is also about safety related to the stability of life resulting from having satisfactory employment, bringing financial benefits. Any negative situation in the area of occupational health and safety management, even if it does not affect the employee directly, it exerts an indirect influence on him. This influence may have a physical nature - disruptions in the work of the individual, or non-physical - related to the functioning of the enterprise on the market, eg: dismissal, deterioration of the material situation.

Given this dual effect of health and safety management and the functioning of the human enterprise, it is necessary that each of these spheres was discussed and analysed in the process of academic education. It should be noted that security rules are created for the purpose of personal protection of individuals, but also to protect the company and all its members. The company is a compact system. Each distortion in its element affects other elements as well as the whole. This is a particularly important issue nowadays in times of dynamic change.[5]

\section{Methods of academic education and teaching effectiveness}

Work, as every field of human functioning, has been undergoing and is still undergoing developmental changes. It results from technical and technological development. Newer and more sophisticated technical devices, new technologies contribute to limiting the importance of traditionally important factors of employees' efficiency. First of all motor skills, but also in some sense also experience are displaced by the knowledge and ability to operate devices. The work of individual, not the group, that counts.[6]

These changes must have its reflection in the education process, including the one, at the university level. Attention should be paid to the knowledge of the possibility of using new solutions, and if possible, the ability to use them. It is necessary to develop the thinking skills - to acquire and analyse information and inference. Pay attention to anticipating events and identifying and correcting irregularities before they cause interferences[7].

Not so long ago, the acquisition of knowledge consisted, above all, of completely or almost completely uncritical memorization of specific principles and rules. At present, what counts is creative thinking, matching and drawing conclusions. These factors have to be the basis for the selection of forms and methods of teaching[8].

Forms which are part of the methods, occur in two basic types: giving and seeking. The first one is represented in academic education in the form of the lecture. According to the idea, the student relies on the teacher's knowledge, which he obtained earlier. According to the author, the lecture should not be a monologue. The transfer of knowledge should be interrupted by free conversation with students, which is based on the analysis and examination of the level of understanding and comprehension. This is to serve their activation. It also has to give the opportunity to speak on the topics discussed. Students, especially those who work, often have resources of practical knowledge. The monologue, in which there is the possibility of discussion, gives each of the parties the chance to gain the new knowledge, or arranging already possessed knowledge and better understanding it. Such features are characterized by the problem or conversation lecture[9].

Searching forms are represented in the process of academic education by: exercises, projects or laboratories. As a rule, they are to allow students to acquire knowledge and skills as a result of their own work (problem solving) under the supervision of the teacher[10]. During the course, the teacher gives the knowledge how, for what purpose, what are the different possibilities of solving, reasons, to solve a specific problem. The student's task is, first of all, to develop skills and gain knowledge of what to do to solve the problem. Both forms of giving and seeking should be based on teacher's partnership with students. Only in such way is it possible to transfer knowledge, to develop skills. This is particularly important in the case of health and safety field of study.

The determinant of academic education is the effectiveness of the employee in the workplace. Therefore, it should be stated that studying should give the opportunity for individual development. It should familiarize with the technical solutions used in practice, give the opportunity to develop skills and acquire knowledge.[11] One of the most important effects, especially in the field of health and safety at work, should be to respect others and to be aware of the impact of occupational safety and health on the human life, but also the employing company. 


\section{Academic education in the field of health and safety - analysis of the conducted research}

The first stage of the research, which was related to the author's desire to gain practical knowledge of the approach to health and safety in enterprises, were interviews with employees and business owners. They were people known to the author. The aim of acquiring knowledge was to use it in the course of didactic classes in the field of Health and Safety on subjects related to the improvement of the health and safety management system, including hazard identification, information analysis and improvement itself. The assumption was that practical knowledge gives the opportunity to refer to real cases, which in itself is interesting for students, in addition to becoming the initiating factor in discussing and analysing cases known to students. In the author's opinion, referring to reality gives better effects in the education process than providing dry definitions or patterns to be used in the future in practice.

During the interviews, employers pointed out the recklessness of employees, eg: an employee came to work under the influence of alcohol, and his work consisted of pouring mortar on a metallurgical furnace operating at that time. The length of continuous work in the period between rest is 5 minutes. The work is very dangerous, and as a result of the necessary inspection, the employee is released. One of the employers admitted that as a result of the downplaying of the dangerous situation (a significant influence here was routine) and proceeding in violation of health and safety regulations, he was electrocuted with a voltage of $380 \mathrm{~V}$. In one production plant during the winter, the owner offered alcohol to employees before starting work. This was due to working conditions. The hall was made of unheated sheet metal. In another enterprise, only one coke oven was installed in the sheet metal halls for heating in the winter period. Over 20 people worked at the same time. One of the employees of another company (carpentry) after cutting his finger off (while working), went to the hospital on his own.

Getting into possession of such knowledge, has provoked the author to hold conversations with the students of health and safety in the subject matter of what health and safety is for them and what experiences they have in this regard. Working students often pointed out that in their workplace, there is a belief that occupational health and safety is first of all training, which is on the one hand a break from work and on the other a waste of time. According to students, this resulted from the monotonous and unattractive form of classes, and, surprisingly, often from the wrong approach of the management staff.

The final stage of the research was to conduct a survey, to which the students of the Faculty of Management at the Czestochowa University of Technology were subjected. The aim was to identify factors influencing the effectiveness of the education process on the direction so important for the functioning of contemporary enterprises. The aim was also to examine the approach to health and safety management among current and future employees and employers. The author also wanted to find out what type of activities are preferred and what students expect. The research carried out in 2018 and involved 93 students, enrolled in full-time and part-time studies, at 1st and 2nd degree studies.

Among respondents, 36 persons (38.71\%) declared being professionally active. Among them, $41.67 \%$ were employed for less than 2 years, $30.56 \%$ from 2 to 5 years, $13.89 \%$ from 5 to 10 years and $13.89 \%$ were employed for over 10 years. Health and safety is related to the health and lives of employees, it is also an area perceived as important for gaining a competitive position. Therefore, it was necessary to identify the reasons for which the respondents began education in this field. The reasons for starting studies also remain in relation to the expectations and assessment of the methods and forms of education used. The most selections among both working and non-working students concerned the position "because there is a need for people responsible for health and safety at every enterprise", respectively: $52.78 \%$ and $29.82 \%$. In the second place among the surveyed employees there was the position "I am interested in this issue" $19.44 \%$ and a set of individual answers that can be combined into a group "suggestion or need at work" $19.44 \%$. In the case of non-working respondents, there is a noticeable low diversity in the number of responses in terms of positions: "I did not have a better idea, someone I know previously studied it or studies now" $26.32 \%$, "because this is the specialization on time" $22.81 \%$. On the basis of the answers received, it should be stated that, above all, people employed were and are more aware while choosing this direction.

The next step was to examine the awareness of the importance and approach to health and safety in enterprises. The results obtained in the group of employed persons are based on both practical and theoretical knowledge acquired in the process of academic education. In the case of the group of respondents without employment, they are associated with knowledge gained during classes and heard during their everyday life. When asked about the importance of health and safety management in relation to the competitive position, the "very important" option was marked by a similar percentage of employed and non-working people: $11.11 \%$ and $10.53 \%$. Position ,big importance": $30,56 \%$ and $42,11 \%$. Position ,average”: $41,67 \%$ and 24,56\%. Position „small”: $11,11 \%$ and 10,53\%. Position „does not matter”: 
$2,78 \%$ and $3,51 \%$. Position ,it is hard to say": $2,78 \%$ and $8,77 \%$. On the basis of the obtained results, it can be stated that the awareness of the impact of health and safety management on the effectiveness of the enterprise is knowledge acquired to a greater degree in the classroom than during professional work. Among the reasons for this state of affairs, there seems to be a dominant approach to health and safety in enterprises, which will be presented in the analysis of the next question.

When asked about the approach to health and safety in enterprises, the largest number of people indicated "attention is paid to obligatory training - health and safety as an effect of the functioning of laws and regulations" $38.89 \%$ of employed, $31.58 \%$ of non-working. The second position in terms of the number of markings was "draws a lot of attention, but it is not strictly applied to the requirements, rules and procedures": $27.78 \%$ of employed, $28.07 \%$ of non-working. Differences in the attitude of people with and without employment were observed in relation to the next positions. Employed persons as third ranked the "attention in situations of negative events and during mandatory training" $19.44 \%$ - for comparison people without employment $14.04 \%$. Workers more often pointed out "pay attention to and control over the application of requirements, rules and procedures" $26.32 \%$. For comparison, this position was indicated by only $13.89 \%$ of respondents- the lowest percentage of selections.

The analysed answers to the previous questions were an introduction to the part of the questionnaire, which was used to assess the methods and forms of academic education used and to identify those factors that affect the effectiveness of this education. Taking into account the opinions of students heard and attendance at classes of particular type, the expected distribution of answers to the question about the "preferred type of classes" was obtained. Students most often marked classes in which they participate, on the principle of solving problems and tasks, namely: exercises $-44.09 \%$ and projects $-39.78 \%$. The lecture had the least interest $-16.13 \%$ of responses.

The next question was requested for comment on the "best way of acquiring knowledge." It was possible to mark 2 items here. Similarly to the previous one, the greatest support was noted in the case of: exercises - 70 selections, projects - 63 selections. The lectures were selected by 31 , and the independent search for answers in the literature by 18 respondents.

The next step was to identify factors that affect the attractiveness of didactic classes. It could be expected that there will be discrepancies depending on whether the respondent is employed or not. This was confirmed in the obtained response schedule. Students working indicated the commitment and knowledge of the teacher in the first place $-47.22 \%$. In the opinion of $30.56 \%$ of them, individual interests are important. This is due to the needs of workplaces, position occupied and orientations by superiors. In the case of non-working people, the most important factor turned out to be: technical means supporting the didactic process $-38.60 \%$. This probably results from the attractiveness of didactic classes with the use of a practical form of knowledge transfer. In the next place, the teacher's involvement and knowledge was indicated $29.82 \%$, and at the following one, the type of classes $-17.54 \%$. Technical support measures and the type of classes in the opinion of working students are less important. Both options were chosen by $11.11 \%$ of respondents. On the basis of the answers received, it should be stated that what is most important in terms of the attractiveness of didactic classes in the process of academic education is the knowledge and commitment of the teacher actively using technical support measures.

The confirmation of the above is the distribution of answers obtained in the question about the expected characteristics of the academic teacher in the context of the effectiveness of knowledge transfer. Both, working and non-employed persons, indicated that the most important thing here is: having and using practical experience $-61.11 \%$ working, $42.11 \%$ non-working. In the opinion of both groups, the second place was occupied by the ability to choose technical means supporting the education process, respectively: $25.00 \%$ and $29.82 \%$ answers. In comparison to this: the easiness of establishing contacts was indicated by $11.11 \%$ of employed and $15.79 \%$ of not working. High requirements were noted by: $2.78 \%$ of employed and $7.02 \%$ of non-working respondents.

The next question was on the approach to acquiring knowledge and education in the field of health and safety, including the impact of management in this area on the functioning of the enterprise. The question was related to the issue indicated in many subjects, but also in the literature of the subject, the need for continuous acquiring knowledge. As a continuous process, it was recognized by $41.67 \%$ of working students and $35.09 \%$ of non-working students. However, it was the second position in terms of the number of selections. In the first place was the position: periodically in accordance with the schedule of own and employees development- $44.44 \%$ of employed and $43.86 \%$ of those not working. Despite the small percentage share, it is surprising, that $11.11 \%$ of employed and $14.04 \%$ of non-working respondents indicated the answer: ,periodically planned trainings". „It is difficult to say” was chosen by $2.78 \%$ of employed and $7.02 \%$ of non-working respondents. The obtained results allow to state that there is a large 
awareness of the need for continuous education and gaining knowledge in the field of health and safety. However, it is still insufficient. This may result from the traditional approach in enterprises, but also in the society where health and safety is primarily about training and compliance with applicable rules.

Issues related to health and safety require continuous individual thinking, observation, analysis and anticipation, as well as group work skills. In connection with the above, the next two questions were aimed at identifying the approach to the needs of shaping such approach among students in the process of academic education. With regard to individual thinking, observing, analysing and predicting, $83.33 \%$ of working and $78.95 \%$ of non-working students regarded as very important and important. The rest considered them as of medium or low priority, or they marked the position „difficult to say”. A similar distribution of responses was obtained in relation to the importance in the process of education, shaping the skills of group work. Very important or important, was chosen respectively by $86.11 \%$ working and $78.95 \%$ non-working respondents. The rest of the respondents considered this as moderate or not important or indicated the position ,it is difficult to say".

\section{Conclusion}

Acquiring knowledge and skills is one of the requirements for employee development. Considering the impact on the health and lives of others and the occupied competitive position, one of the most important directions is health and safety. Since the goal is to avoid the possibility of disturbances, as well as the possibility of their subsequent appearance, it should be recognized that a particular interest in health and safety studies should be addressed to the issues of thinking, predicting, searching, analysing and reasoning. The learning process should therefore be based on trust, discussion and teacher-student partnership. This is important because it favours the acquisition of knowledge and, secondly, affects the future professional approach of the student (future employee) - so it is knowledge in itself.

\section{References}

1. Polish Language Dictionary available at: https://sjp.pwn.pl/slowniki/studiowanie.html

2. K. Klincewicz (red.), Zarzadzanie, organizacje i organizowanie - przeglad perspektyw teoretycznych, Wydawnictwo Naukowe Wydziału Zarządzania Uniwersytetu Warszawskiego, Warszawa, 63, (2016)

3. B. Kalandyk, R. Zapała, M. Maj, Systemy zarządzania BHP w przedsiębiorstwach, Archives of Foundry Engineering, 10/2, 83, (2010)

4. P. Bąk, M. Kapusta, Rola bezpieczeństwa $w$ zarządzaniu przedsiębiorstwem, Zeszyty Naukowe Uniwersytetu Szczecińskiego no 74, t. 2, 13, (2015)

5. A. Cierniak-Emerych, Kształtowanie bezpieczeństwa i higieny pracy $w$ przedsiębiorstwie a cechy kultury organizacyjnej, Edukacja Ekonomistów i Menedżerów. Problemy, Innowacje, Projekty, no 4(26), 88, (2012)

6. L. Dulina, M. Gaso, M. Kramarova, D. Plinta, Wydajność pracowników i ergonomiczny program prewencyjny, Zarządzanie Przedsiębiorstwem, 3, 2, (2017)

7. Skuteczne zarzadzanie jako narzędzie zapobiegania wypadkom przy pracy, FAKTY, Europejska Agencja Bezpieczeństwa i Zdrowia w Pracy, available at: https://osha.europa.eu/sites/default/files/publications/documents/pl/publications/factsheets/13/Factshe et_13__Skuteczne_zarzadzanie_jako_narzedzie_zapobiegania_wypadkom_przy_pracy.pdf (2019)

8. A. M. Wiśniewska, Formy i metody nauczania w szkole wyższej, Kwartalnik Naukowy Uczelni Vistula, 1(51), 150, (2017)

9. Division of education methods: https://www.wpia.uni.lodz.pl/files/articles/95/opisy/9_metodydydaktyczne.pdf

10. J. Wnęk-Gozdek, Formy i metody aktywizowania studentów, Współczesne wyzwania dydaktyki szkoły wyższej, pod red. A. Domagała-Kręcioch, Wydawnictwo Naukowe Uniwersytetu Pedagogicznego, Kraków, 150, (2009)

11. J. Konopka, Wplyw efektywności form szkolenia pracowników na konkurencyjność firmy, Zarządzanie kapitałem intelektualnym w organizacji inteligentnej, pod red. W. Harasim, Wyższa Szkoła Promocji, Warszawa, 102, (2012) 